\author{
Maja Piotrowska \\ ๑ https://orcid.org/0000-0002-6607-4518 \\ Independent researcher cooperating with the Institute of Philosophy, \\ University of Warsaw and the National Museum in Warsaw \\ maja.piotrowskatryzno@gmail.com
}

\title{
PIERRE BOURDIEU ON ART AS SOCIAL PRACTICE. THE DEFENCE OF THE CONCEPT OF THE AUTONOMOUS FIELD OF CULTURAL PRODUCTION
}

\begin{abstract}
The article's aim is to reflect on the late poststructuralist conceptualisations of social practices and autonomous fields of cultural production by Pierre Bourdieu in order to distinguish the specificity of the autonomous field of art and to grasp the author's attitudes to these theoretical constructions. The autonomous field of art is being drawn in the late thought of the French thinker as one of the still existing structures of historical character enabling cultural production and reproduction that is relatively free from external pressures, favours the accumulation of knowledge and enhances reflection. As such - it is diagnosed as a contemporary value in need of defence. The author of these considerations tries to extract this diagnosis, with which she agrees, form Bourdieu's thought. She also attempts to point out the most important, according to her, humanistic traditions which enabled some selected approaches to the theory of practice of modernity and late modernity, and thus the development of Bourdieu's ideas towards emancipation.
\end{abstract}

Keywords: Pierre Bourdieu, theory of practice, autonomous cultural production, poststructuralism, defence of the autonomy of art, the rules of art

Do we need the term 'art' in the face of continual, disorienting, Protean transformations of objects and activities classified as artistic ones? Does it not seem to disturb in the presence of the problems with defining art due to the large number of objects and practices, due to pointing out of diversified, competing with each other practices of conceptualisation of phenomena associated with art - some of them striving for more generalised objectivation, such as the institutional theory of art, and other rather for postulated subjectivation, 
such as hermeneutics of reception, and due to pointing out on coexisting in contemporary art various ontological and metaphysical assumptions? Is 'art' a set of phenomena that can be embraced in a cohesive and nuanced manner by an explanatory theory? Should this term be replaced with other ones that would depend on particular contexts of relations to the art and its limits? Are contemporary thinkers able to grasp the meaning and the sense of this term in ways applicable to numerous artistic phenomena, also the ones that not so long belonged to non-artistic domain, such as, e.g. the forms of design?

I will try to answer these questions invoking selected contemporary humanistic concepts relating to social practice and the knowledge acquired through practice - first of all late Bourdieu's thought with its key ideas. I will also point at some of the most important modern and contemporary intellectual traditions enabling such conceptualisations. Finally, I will try to suggest and emphasise the Bourdieu's purposefulness of the special distinction of the rules of autonomous field of cultural production and autonomous art, and to assume an attitude towards such distinction.

Bourdieu's theoretical proposal to build a theory of specific, autonomic, modern and contemporary social practice that have emerged in the Western culture, is based on the ideas used by him in relation to the entire field of cultural production (i.e. broadly understood sets of created by people phenomena, material culture and practices).

One of the key terms used by Bourdieu is the field; it seems that the field of separated social practice is, first of all, a set of rules in place at given separable in historical time social game, often coded by an explicit term (e.g. art, literature, science, philosophy, economy), which can be defined by a sort of durability. The idea of social game inspired by late Wittgenstein is defined as a set of practices enacted according to grasped in numerous ways rules of taking actions (which according to Bourdieu are objective in given time), with certain stakes (wins), with the assumption of the involvement of the participants. The modern and contemporary art game - the game of autonomous field of art - is not only the place for participation of objects and artistic phenomena (activities and objects given to be seen, to be read, staged, performed etc.), but also of all social practices connected with the production of art in given time, such as creation (production of art by authors), reception by the audience, commercial and media impact on the autonomous field of art, practices of 'lawmakers' (of museums, galleries, educational institutions, various sorts of opinion leaders, possessing some economical or/and symbolic power over the field, also of those who aspire to define the proper, according to them, in given moment, content of the field), their methods of 'consecration' (of confirming the validity of the presence of an work of art or an artistic activity in the field), but also gestures of rupture, defining invalid presence of some parts of the 
previous cultural production in the field due to their not accepted any more character - ageing (artistic manifestos and critics' activity are very convincing Bourdieu's examples of this last practice). The distinguished participants of the game of the autonomous art field are also artists and other creators of culture recognised as individuals active in the game - actors (the idea can be understood analogously to those used in the sociological actor-network theories and compared to the so-called, human actor in Latour). The basis of their operation is habitus.

The idea of habitus for Bourdieu doesn't have ultimately determining character, which could fully explain the actions of individuals. It is rather supposed to bring out the specificity of temporarily coherent practices of individuals, in the sense similar to the one found in late Wittgenstein. We should remember that the character of such actions is changeable (they include modifications of the forms of works of art, performances, formulated goals, changes of the methods of seeking for own place within or outside the autonomous field, responses to rejection and 'ennoblement'). The habituation of creative individuals in the field of autonomous art takes place in the interaction with the structure of the field - its permanent demands and more 'superficial' changes (which are, e.g., approved by the 'lawmakers' artistic currents and single cases of recognition that also change under the influence of external sanctions, e.g. coming from political power). The habitus also results from own (belonging to individual) patterns of socialisation, inclinations, personal experience, built-up and abandoned changeable structure of goals.

An individual (but also a group) can and should (according to the rules of the autonomous field of art) undertake innovative activities and cause a rupture with previously 'consecrated' artistic traditions. However, the returns of forms and postulated goals are possible, e.g. as demands for recognition of references to earlier solutions (such as figuration or socially engaged art) after the periods of negation of such traditions.

Recurring references to the history of the field are possible as the autonomous field of art is highly (and still increasingly, according to what Bourdieu writes in The Rules of Art. Genesis and Structure of the Literary Field ${ }^{1}$ ) selfreflective - the transformations of forms and goals of currents and individual manifestations of art are associated with reflection on the entire tradition of autonomous art - understood as not determined by non-artistic claims coming from outside this field (directly from political or economic power, e.g. from the clients, or defined in advance social utility). It does not mean that the prac-

1 Which refers primarily to the literary field, but also contains very numerous extrapolations regarding the autonomous field of art. See: P. Bourdieu, The Rules of Art. Genesis and Structure of the Literary Field, transl. S. Emanuel, Stanford University Press, Stanford 1995. 
tices of the field are not impacted by symbolic and economic powers - they intermingle with all the practices of autonomous fields in the meaning close to Foucault's power-knowlege impact. In Bourdieu, the tension between the economic and symbolic powers constitutes the very structure of the field.

One of the permanent rules of its functioning is the camouflage of the economic and symbolic benefits that can be reaped by entrant actors thanks to the participation in the game. Since active opposition of economic and symbolic capitals is one of the main rules of the structure of the field, it cannot function in separation from economy. This camouflage is not presented by Bourdieu's conceptualisation as cynically motivated, to the contrary, it rather results form the dynamics of the field, which can be compared to an investment in a salvation game (comparison mine - M. P.). For a creative individual, the game of art is first of all a sort of hazard connected with the requirements of purity of intentions - disinterestedness showing itself in the attitude towards ideas (one can represent others or some ideas, but should not openly present own economic interests). The place to be taken in the field is not clearly specified (experimenting, individuals rely on often intuitive knowledge based on already existing field practices); one may aspire to a high position, but no any safety guarantees are connected with it - we deal with a liquidity of positions, a continuous supply of new proclamations of important and innovative at given moment art, and lack of any financial security. An ascetic distance should be maintained to the dimension of financial security and uncertainty of status. The prize (with no guarantees of its permanent nature, according to the rules of the game) can come or not - it is the consecration ${ }^{2}$ and often following gradual institutionalisation of a new phenomenon or type of artistic practice. Temporary winning is associated with big benefits - mainly symbolic, but often also economic (the accumulation of cultural capital can be taken as more dependable). However, individuals and groups aspiring to positions in the field basically do not control the great number of factors of consecration, although they often attempt to require it and support it. The high position associated with the consecrations and institutionalisation of given method of practising art does not provide lifetime guarantee of security due to the rules how the field works - they assume continuous undermining of effectively 'sacralised' forms and practices, the reception of which in the field of art has already become to some extent a routine and a ritual. Often the next questioning (as shown by Bourdieu in his very detailed historical-sociological-anthropological analyses of the conditions of emergence of particular movements and proposals in his

2 The use of terminology from the field of sociology of religion shows Bourdieu's inspiration by Weber and Durkheim. 
Rules of Art...) takes place due to entering the field by the next generation. It happens that it takes place several times during the lifetime of the consecrated ones.

It should be stressed that in Bourdieu, the structure of the autonomous field of art is a historical construct (therefore, it is not a Lévi-Strauss type structuralism, but poststructuralism, although it owes a lot to anthropological conceptualisations, also to Marcel Mauss). This construct emphasises permanent features distinguished in the analyses - the rules. Some of them, such as the assumption of autonomy, the imperative of innovation, or the struggle for recognition, seem obligatory for the entire field. We may say that these are its irreducible aspects. Simultaneously, Bourdieu kept stressing that achieving the proper view of the current situation in the field of art (and other separated autonomous fields) is connected with the necessity to conduct each time detailed investigations. Emphasising of such historically (and spatially) grounded conceptualisations as the one of autonomous field of art was connected with placing by Bourdieu of his own concept of research in the field of science which also is autonomous, in case of which a reflection on its assumptions and the possibility of their revision (Kuhn's paradigm changes), as well as the applicability of research methods and results - their practical usefulness - are assumed. Although Bourdieu's scientific ambitions and attachment to objectivity met with criticism, the reconstruction of which would go beyond the assumptions of these considerations.

Instead, I will try to take a closer look at another issue, which is important due to my attempt to clarify the rules of functioning of the field of art in the late Bourdieu's thought: how the "rules of art" are captured by the actors. If the majority of contemporary theoreticians have problems with it, my previous mentioning the intuition as a mean of this grasping without any attempt to better define its possible meaning would be a significant reduction of the explanatory potential included in Bourdieu's conceptualisation of the rules of the field.

To develop this thread, we must refer to the idea of practice as it was pondered in many humanistic traditions in the 19th and 20th centuries, in ways contributing to the theory of practice of Pierre Bourdieu. For the start, one should mention American pragmatism; in the early period of his philosophical work, Peirce had formulated the so-called pragmatic maxim, which suggests that indicating the rules of conduct is a good method of explanation. Understanding rooted in practice can be found also in late Husserl (intersubjectivity aimed at resolving practical problems), in Heidegger (his idea of presence athand provides routine understanding, Being-in-the-world can be characterised as pre-reflective, non-reflective - though connected with consciousness, these are the practices of das Man mode, and the concept of dwelling draws attention to what is local), in Merleau-Ponty (incarnated understanding, silent cogito - 
pre-reflective and inarticulate grasp of the world). The observation, description and analysis of social practices are the methods of ethnography, ethnology and cultural anthropology. The sociological investigation of daily situations was developed by the so-called micro-level traditions, e.g. ethnomethodology. In some linguistic theories, language is opposed to praxis. In de Saussure, language can be understood as a symbolic order, while speech should mean the methods of its practical implementation. In late Wittgenstein (in Philosophical Investigations $^{3}$ ), the linguistic meaning of some rules of a game (interaction) can be grasped only during the course of an activity or in its detailed descriptions the philosophers' language games don't offer the possibility of the complete understanding of the forms of life. In The Rules of Art..., Bourdieu noticed that, similarly to art, philosophy formed also a highly formalised autonomous field, which despite the analyses devoted to its history, does not know well the nuanced social history of its own development. The contemporary gap between logos and praxis was derived by the French thinker from the history of the Western educational practice - the language used at school got detached from the practices of life and created a separate communication tradition (of rhetoric, description and analysis), a peculiar exercises of non-doing.

Now let's have a look at the idea of rule, in particular in Bourdieu, but also in Wittgenstein - one of his main sources of inspiration; in the Philosophical investigations, language and communication mean practising of some rules of life. Also in Bourdieu, the language of art (the language of the author) first of all seems to be the communication with the recipients and lawmakers with 'compatible' habitus - the communication practising the rules of the field of art - hence, it encounters recipients who are ready to follow the same (sometimes unrealised) rules, or who come forward to new (one could say - more 'superficial') in the context of field. The continuity of formal search within an autonomous field of art means that by creating new rules, authors refer to the already existing ones. The fact that the majority of theoretical approaches cannot outline the rules of functioning of the field of art is in the context of the thought of Bourdieu to large extent connected with the tradition of a discourse separated from the practices of forms of life. The discourse concerning art focuses most of all on the work of art, on itself, on the experience of the subject (which means first of all the theoretician who is often isolated from understanding of his/her own practice of understanding in the reception process). There are created models of understanding that do not or poorly reach the intended by Bourdieu extended historical meaning of a work of art - such meaning is

3 See: L. Wittgenstein, Philosophical investigations, transl. G. E. M. Anscombe, Basil Blackwell Ltd., Oxford 1986. 
closely linked with the multi-dimensional social history of the author and his/ her practice of art, consecrating institutions, etc. Most often, the discourse concerning art does not offer the knowledge of broader historical and social conditions of the actions of the individuals, and the understanding of understanding itself (according to Bourdieu, without historical and sociological investigation of the methods of understanding of understanding, as well as without in-depth knowledge of the social history of the field ${ }^{4}$ - not only the history of forms, traditionally understood biography and contemporary theories of art - it is not possible to cohesively comprehend the practices of the game of art with its numerous nuances).

Getting back to our grasping of the idea of a rule - in late Wittgenstein, understanding was seemingly joined with the possibility of continuing actions. In Bourdieu, it was allied also with the stressed possibility of superficial rupturing of the continuation and with undertaking actions possible to be noticed in the field as understandable continuations through denying its past and present practices. Charles Taylor assumed that for Bourdieu rules were the patterns of motivating actions - such a rule is fulfilled by a practice, which is often shaping it. ${ }^{5}$ In Wittgenstein, practice decides about the actual meaning of a word, both in the process of language learning by a child and later, in the process of acquiring competences in language games (by pointing out at something, examples, participation). Customs, traditions and institutions with their specific practices constitute a world of applications of rules which are often not predefined; one can imagine, as Wittgenstein wrote, that someone has learnt how to play, though he was neither learning any rules nor formulating them. We may assume that taking action according to a rule often means non-reflective habitus; the rules are being established in an uncodified form and can be written down after some time, though they don't have to be established as written at all. These rules seem to be illustrated by examples of problems with formulating general terms concerning the autonomous field of art, which, moreover, can be and actually and usually not understood as a game, or even a system in which more stable rules can be found. In the case of rules, both Wittgenstein and Bourdieu were aware of the ambiguity of the term. Bourdieu distinguished at least three meanings of it; one was an applied legal principle, another - a set of regular

4 In which he approaches the so-called strong program in sociology of knowledge (of Edinburgh-based school of thoughts) - the investigations of the relations connecting knowledge, science and social factors, also to Foucault and the Annales school (School of history).

5 See: M. Pancewicz-Puchalska, Wybawca Wittgenstein? Problem regut w teorii praktyki Pierre'a Bourdieu, Studia Litteraria et Historica, 2017(6), Institute of Slavic Studies, Polish Academy of Sciences, Warsaw 2017 in: researchgate.net/publication/323240681_Wybawca_Wittgenstein_Problem_regul_w_teorii_praktyki_Pierre'a_Bourdieu, p. 9. 
practices obligatory for everyone in a given social game, the third was understood as a scientific model used to explain the practice. In the field of art, an observed regularity is often perceived as a set of rules that the actors follow this phenomenon seems to explain sometimes quite anxious reactions of some theoreticians to the multitude of forms of modern and contemporary art, and the recurrence of previously 'worn out' styles; the observed regularities don't seem to form any kind of sensible or understandable pattern. In fact, what is being searched for, are rules - the principles of the game, yet they are not being found, because a theoretician approaches the field from the inside, without the necessary distance, like participating artist, but usually he/she has no artistic type of habitus at his/her disposal. The task and methods of the investigator in Bourdieu's thought differ from these of the artists - the theoreticians, as it seems, should not participate in the game in an artistic manner, or not only in such a way.

It should be added here that also the French thinker was basing on regularities, but in ones found in the sphere of historically-sociologically recognised practice, in multidimensional descriptions of worlds of life colliding with and transforming already formed structure of the field. Bourdieu was avoiding searching for conscious rules of coherence of the field, he was wary of emerging ephemeral ('surface') rules for immediate application, and also for the subjectivism of individual projects. Apparently, he was assuming a kind of social unconsciousness, a certain gap between the discourse and activities, practices and the real structure of rules operating in the field (though this gap was not seen as impossible to be bypassed).

Also Anthony Giddens formulated a theory of practice - taking place between the subjective and objective dimensions, combined with the concept of structure, understood as a set of rules and resources (one could try to determine, to which extend the resources correspond to Bourdieu's capitals). The structure in Giddens can be put as the result of the differentiation of practices, the power factors can be defined by the allocation of capital and authority (which seems to be built by knowledge and the ability of individuals). It is often being recognised, that Giddens was more interested in the theory of structuralisation, and Bourdieu rather in the theory of reproduction of practices. In Modernity and Self-Identity... ${ }^{6}$, the procedures used in the establishment and reproduction of social behaviours have been distinguished as some aspects of practice. The application of these rules often takes place in an uncodified manner. In addition, the rules can be used in different circumstances, which seems to correspond to a certain temporal unity of Bourdieu's habits. In analogical

6 See: A. Giddens, Modernity and Self-Identity. Self and Society in the Late Modern Age, Polity Press, Cambridge 2006. 
contexts, Giddens speaks about rules, of which the subject may be aware, but not necessarily, and Bourdieu rather about the dispositions, which also means strong impact of early socialisation. For Giddens, the majority of the rules seem to be of unverbalised character, although they are placed in the consciousness, which is practical. The practical awareness is here rather a discursive one; what is unconscious in Giddens, will mean content that is non-conscious at the moment. ${ }^{7}$

In Bourdieu, a significant role in building of the gap between a potentially clarifying discourse and practitioners is played by the sacralisation of the game of art, which seems to have borrowed many patterns of behaviour from the religious attitudes (e.g. confirming mysticism/metaphysics of the presence in the work of art, ritualised visits in museums and galleries, ceremonial recognition, etc.). However, important in the Bourdieu's project desacralisation and intention of revitalising by deritualisation of the attitude to art do not seem to serve to reduce the values conveyed by art which is highly autonomous or, especially, the value of the autonomous field of art itself. (At the same time, Bourdieu was aware that using language partially derived from natural sciences to speak about fields sanctified and rejecting sacralisation can arouse emotions and expose himself to attacks, and was trying to secure his position against them). It is also hard to find in his ideas any aim to reduce the value of individualised experience of art, rather only opened possibility of better understanding of the transcending individual level of understanding is being stressed, which, as he believed, broadens the horizons of understanding in general, as well as research conducted carefully in different fields. It can be assumed that Bourdieu believed in rational agreement (it can be even said that his late thought suggests a specific 'upgrade' of Habermas' project), based on descriptive studies involving all sociological forces, using statistics, examining one's own position as a researcher/thinker and current own ways of understanding, plus the modes of understanding present in the history of the investigated field. Bourdieu's achievements - a research method, designed to be applied, very demanding, yet so convincing that often implemented, recently was used in Poland to study the field of literature after the systemic transformation.

Due to implementations, it is often pointed out that the concepts integral for Bourdieu are imprecise. It should be noted that they are not defined preci-

7 "Practical consciousness is integral to the reflexive monitoring of action, but it is "nonconscious', rather than unconscious. Most forms of practical consciousness could not be 'held in mind' during the course of social activities, since their tacit or taken-for-granted qualities form the essential condition which allows actors to concentrate on tasks at hand." A. Giddens, Modernity and Self-Identity. Self and Society in the Late Modern Age, Polity Press, Cambridge 2006, p. 37. 
sely in his works, instead they are rather built cumulatively in repeated relapses of taken up threads. In addition, the concepts are burdened with connotations, the language thinks us, as Wittgenstein noticed, through the identical forms of words. For both philosophers, it seems to be no other way out of this situation than careful reading and careful thinking/analysis. For example, one of the absolutely key concepts of Bourdieu, habitus, can be associated deterministically. However, in Bourdieu, habitus, although determined by its numerous influences, still constitutes a palette of potential capabilities (possibles) of an individual, which is being developed despite all these determinations. Habitus - various forms of practice of life of an individual, can take place in the space of possibilities between what is structurally determining, in the space of tensions between the economy, political power and the values of autonomous culture, in reference to and in addition to existing forms, in the movement of escapes and returns, from and to forms of socialisation specific for an individual. Bourdieu saw the value of habitus - more or less reflective, temporary habituation to the situation in a given field - as an opportunity to reduce wrongly posed theoretical questions and misinterpretations of practice, thus again probably in inspiration of Wittgenstein. One could also build here an analogy with the existentialist tradition of clarifying Being - in the habitus, there is the potential for project-making and self-understanding. At the same time, we should remember that Bourdieu approached many of the ideas of Heidegger with great distance, e.g. the issue of the manifestation of truth in a work of art; although this may be a 'social' truth, we are dealing with sacralisation (one could say - almost mystical participation), based on the recipient's faith and imagination of the contact with the truth of the work, instead of an attempt to understand specific processes affecting the creation of the work. The potential of such a 'truth' of the work is not emancipatory, but conservative, as Bourdieu believed, and such a belief did not attract him; he understood the transmission of culture as postulating the accumulation of understanding and, consequently, expanding the possibilities of rational reflection that creates a (highly valued) space of freedom.

The space of freedom is also created by some of the liberties manifesting themselves in the structure of the field of autonomous art; basing on The Rules of art..., one can conclude that they are primarily: - the possibility of escaping the petrification threatening from the side of the symbolic power in the most general sense (by the way, it is one of the two powers immanently present in all fields, the other is the economic one), - the possibility of renewing culture, accumulation of knowledge, and also - freedom to fight for better conditions of living, e.g. for the control of means of artistic production (what is an idea in a sense very close to Marxism, but deprived of the reduction to the class struggle that comes from that conceptualisation). 
The late Bourdieu's attitude towards autonomous game of art is highly affirmative, though desacralised-disillusioned. The values present in the field of art are supposed to serve people, not the affirmation of the values themselves, objects, or ritualised practices (this was described by the French thinker as fetishism). Also, Bourdieu perceived beauty in the field of art as a fetish, a symbol, one might say, not referring to anything liberating. I cannot agree with him in this matter; one can assume a point of view, according to which beauty is not bound with a specific object or specific activities in order of adoration, but rather with self-awareness/self-reflexivity of the subject who sees in his/her own disposition to perceive beauty the impact of both the field of cultural production and the result of early socialisation (Wittgenstein's naming by pointing is associated with an emotional message, a disposition of delight captured and taken over by the learner based on the reception of the body language, facial expressions and the tone of voice), which may result in a feeling of gratitude that has a chance to strengthen the potential for social involvement. This thread, however, goes again beyond the aim of these deliberations, let us then return to the issue of emancipation in the thought of Bourdieu, which seems to be one of the main goals of his defense of the autonomous fields.

The role of a "laboratory of emancipation" (my term - M. P.) seems to be played by art as well, although the field of game of autonomous art is a field of struggle of various interests and aspirations for legitimisation and, simultaneously, a struggle between symbolic and economic powers; in Bourdieu there is also a field of freedom, in which the creative and reflective disposition of an individual is realised, manipulated by the pressure from external fields to a relatively small degree, and also striving for a real emancipation. In the light of Bourdieu's assumptions, the concept of autonomic art should be preserved as a historical formation with a significant emancipation potential, which is indicating the field of activities, conditions and possibilities storing some values relevant to Western culture.

At the end of The Rules of Art..., Bourdieu ponders the threads of contemporary threats to autonomic fields, such as the exclusion of artists, writers and scholars from the public debate in the result of multiple factors, such as progressing specialisation (forcing the resignation from broad intellectual ambitions), symbolic technocratic power (whose authority increases), commercial control over means of communication (imposing a simplified, shortened and first of all attracting the viewer's attention type of message, also political one, which can be associated with the loss of the intellectual quality of the message), the control of the representatives of power over the means of dissemination of art, and therefore its consecration, to a greater extent than ever before in history (which results in progressing commercialisation of art and getting of forms of social pressure coming not only directly from the market but also from 
the field of organised politics, from the state or journalistic production into the autonomous field of the cultural, imposing the formatting of statements about artistic activities and the artistic activities themselves according to their needs). Bourdieu suggests that autonomic culture is fragile and writes explicitly that it cannot rely only on the heroism of individuals. In the earlier stages of formation and creation of the autonomous field of cultural production (in the process of determining the beginnings of which Bourdieu goes back as far as to Renaissance, a few times writing also about French enlightenment), the necessities of the market were of course also influencing it, but never - as the French thinker claimed in the last decade of the 20th century - in the way as powerful as it takes place today. We have strong reasons to assume that this diagnosis remains valid.

One of the remedies for this situation would be the collective defense of the autonomy of the means of cultural production undertaken by the creators of culture, the establishment of international power of criticism and alternative supervision over the manifestations of usurpations and 'maybe even also' (writes Bourdieu) putting forward the proposals of legislation - it may mean a direct involvement of the creators of culture in politics with simultaneous attempts to maintain their position in the autonomous field. This, however, as demonstrated in the Rules of Art..., is not that easy, in particular for authors deprived of means enabling them not to take care of their financial interests. Leaving the question open: whether it is an utopian proposal or not (whereas answering it would probably require a separate time and labour intensive diagnosis of the situation of the autonomous field of cultural production in various countries carried out according to Bourdieu's methodology), finally, I would like to present a case of a series of artistic activities, which seem to touch the above-presented issues.

Dorota Kozieradzka, Polish contemporary artist, whose works are currently present at important exhibitions of Polish and international autonomous art field $^{8}$, uses her sports practice (she is regularly training as an amateur skater) to develop a project entitled Olympic Charmer; the project consists of a series of stylised photo arrangements and photomontages depicting the author as a sports champion reaching for the highest prizes. The stylisations of her works suggest different stages of media development of the promotion of celebrities, all of them are kept in the glamour style. The project certainly has an emancipatory dimension - the artist in the whole scope of her work also eagerly ponders such topics as pregnancy or ageing, which in just slightly conventionalised

8 Cf. "Force Field”, Giudecca Art District, Venice 2019, and “Inner Life: The Bump”, The Art Scene of 19th New Horizons IFF, galeria studio BWA, Wrocław 2019. 
versions are still taboos for the mainstream media (unless it is the case of sale of unhappiness). The Olympic Charmer seems to suggest, that success in the autonomous field is increasingly associated with commercialised, media-like promotion strategies previously reserved for other social fields. These works make one wonder: Are they becoming quickly legitimised in the autonomous artistic field above all because they question the ways and goals of contemporary (commercial and non-commercial) cultural production, or perhaps because they fit so well in the iconographic schemes using the means/iconography of commercial media? Probably, it would be also justified (in the context of other Kozieradzka's works and also the author's opinions) to note here the criticism of the excessive requirements concerning artists, and especially female artists, forced to combine multiple social roles (which, incidentally, fits in the pattern of asceticism understood as striving for championship leading to the heavenly dimension and/or the heavenly dimension of celebrities ${ }^{9}$ ). One of the author's notes introduces the Olympic Charmer project as a declaration of independence - in art we can be, whoever we want to be. But does Kozieradzka suggest such an actualisation of freedom, which primarily means a media type popularity? It can be assumed that this is not the point here. The artist declares, that her work stays open for interpretation, thus I will let myself interpret the works from the Olympic Charmer series in the context of my previous considerations as a kind of their illustration; perhaps the most important emancipation potential that they contain lies in the possibility of revealing the fact, which is an open secret, a non-conscious rule often overlooked also by the creators of culture: the contemporary patterns and technology used for the promotion of success and its images are being imposed by the media (mainly due to the pressure of economy, which, we should remember, also has its leaders) with such a force that they cause the unification of the commercial and autonomous fields, leaving us, creators (The rules of art... concern primarily literature, and the autonomy of creation is also a privilege of theoreticians and scientists), more and more limited and with predefined possibilities every time when we try to be heard, read or noticed. It may mean that more and more of content of the autonomous field will be identified above all with the patterns of the mainstream one, also in the case of criticism or polemics. The issue of the threat to the autonomy of culture and art now also applies to the increasing pressure from the side of the state - what we can observe as far as nowadays autonomous art field and institutions in Poland are concerned.

9 See P. Sloterdijk, You must change your life, transl. W. Hoban, Polity Press, Cambridge 2013. 


\section{BIBLIOGRAPHY:}

Akçaoğlu Aksu, Wacquant Loïc (2016) Praktyka $i$ władza symboliczna u Bourdieu: spojrzenie z Berkeley, transl. T. Warczok, "Praktyka Teoretyczna" no 3(21).

Bourdieu Pierre (2001) Reguty sztuki, transl. A. Zawadzki, Kraków: Universitas.

Bourdieu Pierre (1992) The Logic of Practice, transl. R. Nice, Stanford: Stanford University Press.

Bourdieu Pierre (1995) The Rules of Art. Genesis and Structure of the Literary Field, transl. S. Emanuel, Stanford: Stanford University Press.

Giddens Anthony (2006) Modernity and Self-Identity. Self and Society in the Late Modern Age, Cambridge: Polity Press.

Giddens Anthony (2010) Nowoczesność i tożsamość. 'Ja' i spoteczeństwo w epoce późnej nowoczesności, Warszawa: Wydawnictwo naukowe PWN.

Kopciewicz Lucyna (2017) Społecznie konstruowane ciała i performatywna magia. Teoria socjologiczna Pierre'a Bourdieu w badaniach performatywnych, "Studia Litteraria et Historica:, no 6 [in:] researchgate.net/publication/323240683_Spolecznie_konstruowane_ciala_i_performatywna_magia_Teoria_socjologiczna_Pierre'a_Bourdieu_w_badaniach_performatywnych, a. 12.07.2019;

Pancewicz-Puchalska Magdalena (2017) Wybawca Wittgenstein? Problem regut w teorii praktyki Pierre'a Bourdieu, "Studia Litteraria et Historica", no 6, [in:] researchgate.net/publication/323240681_Wybawca_Wittgenstein_Problem_regul_w_teorii_praktyki_Pierre'a_Bourdieu, a. 10.07.2019;

Sloterdijk Peter (2013) You must change your life, transl. Wieland Hoban, Cambridge: Polity Press.

Wittgenstein Ludwig (2004) Dociekania filozoficzne, transl. B. Wolniewicz, Wydawnictwo naukowe Warszawa: PWN.

Wittgenstein Ludwig (1986) Philosophical investigations, transl. G. E. M. Anscombe, Oxford: Basil Blackwell Ltd..

\section{PIERRE BOURDIEU O SZTUCE JAKO PRAKTYCE SPOŁECZNEJ. OBRONA KONCEPCJI AUTONOMICZNEGO POLA PRODUKCJI KULTUROWEJ (streszczenie)}

Celem artykułu jest namysł nad poststrukturalistyczną konceptualizacją praktyk społecznych i autonomicznych pól produkcji kulturowej w późnej twórczości Pierre'a Bourdieu, zmierzający w kierunku wyodrębnienia specyfiki autonomicznego pola sztuki i uchwycenia nastawienia autora wobec własnych konstrukcji teoretycznych. Autonomiczne pole sztuki rysuje się w tym kontek- 
ście jako jedna z takich trwających wciąż struktur o charakterze historycznym, które umożliwiają produkcję i reprodukcję kultury; jako stosunkowo wolne od zewnętrznych nacisków, autonomiczne pola produkcji kulturowej sprzyjają akumulacji wiedzy i wzmacniają potencjał refleksji. Jako takie - pole sztuki jest diagnozowane u Bourdieu jako współczesna wartość wymagająca obrony. Autorka wydobywając z konceptualizacji Bourdieu tę diagnozę, z którą się zgadza, stara się także wskazać najważniejsze tradycje humanistyczne, które, według niej, umożliwiły nowoczesne i współczesne ujęcia teorii praktyki oraz rozwój myśli Bourdieu w kierunku emancypacyjnym.

Słowa kluczowe: Pierre Bourdieu, teoria praktyki, autonomiczna produkcja kulturowa, poststrukturalizm, obrona autonomii sztuki, reguły sztuki

Maja Piotrowska - Graduate of PhD studies at the Institute of Philosophy, University of Warsaw (2017) and foreign PhD studies at Universitŕ degli Studi di Padova (2015/16), Master of Fine Arts, cooperates with the Institute of Philosophy, University of Warsaw as co-creator and co-leader of academic museal classes, works as an educator and creator of thematic tours at the National Museum in Warsaw. Her articles appeared so far in Polish magazines devoted to art and philosophy and in numerous post-conference publications in Poland and abroad. She combines her artistic practice with theoretical interests. Particularly interested in sensory and aesthetic perception in context of late modernity. 